\author{
Марина Протас Maryna Protas \\ кандидат мистецтвознавства PhD in Art studies \\ провідний науковий співробітник leading researcher \\ відділ кураторської виставкової діяльності Department of Curatorial Exhibition Activities \\ та культурних обмінів and Cultural Exchange, \\ Інститут проблем сучасного мистецтва \\ Modern Art ResearchInstitute \\ НАМ України of National Academy of Arts of Ukraine
}

protas.art@gmail.com orcid.org/0000-0001-8137-0342

\title{
МИСТЕЦТВОЗНАВСТВО В КОНТЕКСТІ ЕПІСТЕМОЛОГІЧНОЇ ГІБРИДНОСТІ
}

\author{
Art Studies in the Context of Epistemological Hybidity
}

\begin{abstract}
Анотація. В контексті сучасної європейської дискусії про взаємну інтегрованість чи розбіж-ність інтеркультурної та мультикультурної парадигм, в умовах епістемологічної гібридності та домінування арт-ринкової волатильності з'ясовуються чинники низки особливостей розвитку національного культурно-мистецького буття, акце-нтуються хиби мистецтвознавчих оціночних критеріїв, а також наголошується на важливості реактивації традиційних аспектів, відомих як «духовість» теорії й практики, або як кантівсько-гегелівські критерії естетичного досвіду.

Ключові слова: самоідентифікація, національне мистецтво, культура пам’яті, ко-модифіковане мистецтво, епістемологічна гібридність, критерії аналізу, інтерку-льтуралізм, мультикультуралізм.
\end{abstract}

У нас духовність - часто ялове поняття, що прикладається до явищ, при-
четних і непри-четних до культури. І все це називається духовністю: і по-
літика, і еротика, і танці, і графоманство. Так багато духовності, що фак-
тично ядра і глибини цього поняття немає. <...> Духовість - це вже є куль-
турна похідна. I часом вона зовсім не пов’язана з духовною літературою.
євген Сверстюк. 1999 [21].
Майбутнє України вимагає піднесення гуманітарно-духовних цінностей
над короткозорим економічним зиском та політичною доцільністю. Декларація Ініціативної групи «Першого грудня». 2011 [20].

Постановка проблеми. Сьогодні в Україні вважається добрим тоном міркувати про тренди західної культури і мистецтва як про вартий уваги найсучасніший контент. Зазвичай це пояснюють прагненням національної еліти очиститись від залишків радянського колоніального менталітету тих часів, коли призвичаїлись спостерігати, як «відрубали інтелектуальний ресурс», «не дозволяли думати самим», через що панувала «система імітації, яку українці інтеріорізували» [14]. Тепер стара «парадигма закінчилась», і культурні діячі, долаючи постколоніальні наслідки «модерного проекту СРСР» і рабського розуміння творчої свободи, а разом звільняючись від «конвульсій ‘... ренесансної практики репрезентації», свідомо віддають перевагу візуальним практикам особливо там, де виникає підозра, «чи це мистецтво?», (бо «постмодерн - це момент самоусвідомлення модерним суспільством своїх власних негараздів та самоаналіз чи самокритика, в тому числі і через візуальні практики»), відповідно митці воліють гово- рити про кінець доби просвітництва і «виробництво свого категоріального апарату» емансипативної практики, вільної від імітувань [14]. Мета чудова, та засоби сумнівні, хоча б тому, що продовжують абсолютно некритично імітувати цього разу західну модель культуротворення, ллючи у нові міхи старий політизований «символічний мультикультуралізм». Проте розмитість визначення того, що $є$ мистецтвом чи не-мистецтвом, ставить емпірію арт-вислову наших "емансипатів» в ар'єргард світових дискурсів, де точаться суперечки навколо міжкультурного полілогу.

Від зламу 1980-90-х, коли розвернулась критична кампанія проти ідеї мультикультуралізму, перетворюючи її на «об’єкт побиття», була запропонована інша ідея інтеркультуралізму, адепти якої, на думку професора Tariq Modood з Брістольського університету, надто перекручують попередню ідею, розчиняючи ï̈ у політичних теоріях домінування «нормативної значущості більшості», а по суті інтеркультуралізм не є новою парадигмою, і жод- 
ного аргументу стосовно недієвості мультикультуралізму вчений не почув [10; 11, с. 14]. На тлі цієї дискусї̈ українці (митці, критики, науковці) мають сумлінніше аналізувати шляхи якісного культурно-мистецького виробництва власного продукту, уникаючи хиб епістемологічної обмеженості при маніфестації прагнень нації до ЕС і НАТО, та пропонувати Заходу справжню інноваційну позицію коректного розуміння теорії міжкультурного діалогу.

Як зауважує професор Університету Суррея Martyn Barrett, прихильник мультидисциплінарних досліджень у царині суспільних викликів у контексті національного й етнічного міжкультурного діалогу [24], інтеркультуралізм та мультикультуралізм часто вважають різними парадигмами (принаймні у Канаді дефініцію interculturalism застосовують саме у сенсі протиставлення національного культурного різноманіття застарілоспрощеному розумінню дефініції multiculturalism, і цей сенс «відрізняється від європейської моделі інтеркультурності»), проте є вчені, які, припускаючи синонімічність обох термінів, все ж наголошують на актуальності саме новітнього, адже від 1970-х старий термін стає політично заплямованим, тому протягом 2010-х європейські лідери (А. Меркель, Д. Кемерон, Н. Саркозі) прийшли до висновку, що політика мультикультуралізму виявилася абсолютно провальною, адже «інституціоналізує культурні відмінності», спонукаючи до сепаратистських настроїв, послаблюючи колективну ідентичність [1, с. 15-41]. Менш з тим, наголошує М. Баррет, статистика свідчить зворотне: «політика мультикультуралізму фактично посилювалася між 2000 та 2010 роками у багатьох європейських країнах", хоча очевидно, що через політичні і соціальні фактори в різних країнах індекс мультикультуралізму постійно коливається (так зменшили індекс за цей час Данія, Італія та Нідерланди), але констатувати провал політики мультикультуралізму $€$ некоректним (принаймні опитування 2007 року громадян 27 країн-членів ЄС довело, що «три чверті респондентів вважають, що люди 3 різним етнічним, релігійним або національним походженням збагатили культурне життя своєї країни», відтак, «інтеркультуралізм поділяє ряд особливостей з мультикультуралізмом, зокрема цінує культурну різноманітність та плюралізм», «інтеркультуралізм також робить акцент на інтеграцію та соціальне включення... > ..> Інакше кажучи, інтеркультуралізм будує основи мультикультуралізму»). I якщо в Нідерландах більше акцентується згуртованість громади, то Великобританія прийняла модель «плюрального мультикультуралізму», але обидві країні належать до різних груп індексу. Максимально високий індекс мають Австралія, Канада, Фінляндія, Швеція; середній - у Бельгії, Ірландії, Норвегії, Португалії, Іспанії, Великобританії; а найменший мають Австрія, Франція, Німеччина, Гре- ція, Італія, Швейцарія, Нідерланди. Важливо розуміти, що у часі тлумачення мультикультуралізму також змінює фокус: у 1970-х це етнічне фокусування меншин, з 1980-х сенс центрується навколо расових й економічних бар'єрів, з 1990-х — на питаннях громадянської незалежності та соціальній інклюзивності, з 2000-х - виникає інтеграційний мультикультуралізм, що фіксується на питаннях релігійної чутливості, правах і обов'язках, відтак без збалансованого міжкультурного діалогу усі такі питання не вирішити. Маю припустити, що саме в останньому варіанті тлумачення 2000-х ховається і питання національної культурно-мистецької чутливості, та їй тепер не прийнято приділяти належної уваги, хоча без цього полікультурний діалог взагалі втрачає сенс. I мова не йде тут про згадуваний «символічний мультикультуралізм», який українці мали за радянські часи, коли етнічна спадщина презентувалась різними фестивалями, а по суті тривала русифікація; щоправда цей сценарій тепер реалізують «емансипати", асимілюючи західну посткультуру з усім спектром ентропійних проблем. Мова скоріше про «діалогічний мультикультуралізм», всередині і назовні країни, завдяки якому, на думку низки аналітиків, підкреслюється жвавий взаємо-продуктивний діалог не лише у політиці, економіці, але і у мистецтвах, тобто у суспільних «неполітичних сферах життя як об’єднуючому фокусі» [1]. Інакше кажучи, прагнучи у європейську культурну спільноту, маємо уникати хиб і маніпуляцій політизованого мультикультуралізму, тому не варто чіплятися за модні терміни, теорії 3 поверховим сенсом, бо маємо ретельно аналізувати сутність процесів та їх наслідки, адже «інтеркультуралізм заохочує до міжкультурного діалогу, що допомагає людям поглиблювати розуміння культурних переконань та практик відмінних від їх власних, сприяючи ‘... толерантності та взаємоповазі", покращуючи «взаємовідносини між різними національностями, етносами, мовами та віросповіданнями, а також сприяючи інтеграції, почуттю загальної мети та згуртованості культурно різноманітних суспільств» [1]. Або, як зазначав Р. Грильо, "хоча інтеркультуралізм та мультикультуралізм маніфестують різні акценти, важливо щоб вони були взаємодоповнюючими», як міць «інтеграційного плюралізму» [6].

Втім практика вносить корективи через прив’язку мистецтва до політичної й економічної кон’юнктури, що призводить до залежності від ринкових коливань та чергової зміни високооплачуваної еліти, як то сталося з А. Криволапом, досягнення арт-дилерів якого «нині виглядають вітриною, простір за якою маскує певну відсутність наповнення», тому цілком справедливим $є$ твердження, що в мистецькому бутті «гучні події, міжнародні імпрези виносять у заголовки одні імена, через роки дослідники називають геть інші як ті, що вплинули на розвиток, завдали напрямки» [19]. 
Гібридність мистецьких оцінок, що коливається між ринково прибутковим, випадковим успіхом, та намаганням знайти істину, хоч як би ії розуміли, створює броунівський рух, де мов за соломинку хапаються за банально спрощене тлумачення плюралізму: «Зараз ми прийшли не до того, що сколапсував розум і просвітництво, а до того, що певна система пізнання виявилась ієрархічною, репресивною. Вона виявилась не позитивною. Вона експлуатувала багато людей і ресурсів. А $є$ інші способи думання про світ» [14]. Розриваючи тяглість культурних традицій, сучасні просунуті митці фактично виплескують 3 брудною водою надто цінне для нації, нехтуючи культуротворчими традиціями, підмінюючи справжній інтеркультуралізм хибним сурогатом. Принаймні й за радянські часи казали про інші «способи думання", маючи на увазі прояви вищих форм нервової діяльності, і як свідчив $Є$. Сверстюк, слово «душа» також не відкидалося, просто мало інший зміст, позбавлений духовості. Тому через те, що упродовж радянських часів «спадкоємність у нашій культурі переривалася заборонами", від зламу міленіумів українців так само "заїдає втрачений рівень культури", й адаптація західного патерну культуротворення, де немає духовості, руйнівним чином впливає на цю ситуацію, усугубляючи небезпеку [21]. Варто вдуматися у слова предстоятеля Української греко-католицької церкви Блаженнішего Святослава, який тлумачить українську ідею тринітарно: «Український народ існує. Тобто ми є народом, який має свою мову, свою культуру, свою традицію. Ми є народом, який сьогодні має свою державу. Існує як суб'єкт, зокрема міжнародного права»; «ми маємо право обирати свій шлях розвитку. Ми маємо право мати свою незалежну державу. Ми маємо право і обов'язок ії̈ захищати, навіть ціною власного життя. Ми маємо право бути почутими міжнародною спільнотою і бути її невід’ємною складовою частиною»; відповідно: інші мають поважати це право, «поважати нашу гідність, нашу чутливість, поважати шлях, яким ми йдемо, поважати наш вибір» [23]. Та сьогодні частина інтелектуальної еліти України, апелюючи до сутності культуротворчих традицій, констатує: «Втрачено той рівень культури, який зобов'язує до сповідування вершин і плекання принципу правдивості», позаяк «вільна атмосфера плюралізму $\epsilon$ великою мірою "садом великих спокус". <...> спокус легкої думки, кон’юнктури, більш чи менш прихованої», тому як і раніше маємо проблеми анти-культурного існування, коли «високе служіння ... перетворене на обов'язкове вислужництво», коли виміняні на дрібний успіх і легкі гроші «ризиковані спроби відродження інтелігенції всупереч обставинам часу", коли недобрий посів минулого залишився дотепер, вимагаючи від нації сили духу [21]. Через це ініціативна група «Перше грудня» 2011 року декларує: «Хибно зрозуміле матеріалістичне мислення взяло гору над пріо- ритетом етичних і духовних цінностей», «Людина є вільною особистістю, а не придатком державної машини і фінансового капіталу» [20], і саме тому в сучасних умовах епістемологічної гібридності і відвертої когнітивної плутанини, коли «світ стоїть на порозі грізної ери зіткнення національних егоїзмів» [16], так важливо розрізняти і визначати якісний щабель культуротворчих, а разом з тим і мистецтвознавчих критеріїв аналізу з тим, щоб відродити втрачений «той рівень культури, який зобов'язує до сповідування вершин і плекання принципу правдивості». Адже, зазначав М. Попович, без власної духовно та інтелектуально просунутої системи цінностей національної культури, стратегічно узгодженої на століття вперед, наша нація не відбудеться: «Якщо нація не має своєї філософії та своєї музики, то яке в неї майбутнє? <...> Ідеться про те, що спільнота перетворюється на споживача. Вона цікавиться тільки тим, що завтра можна продати» [27]. Цьому сприяє технічний розвиток, який часто сприймають «як результат соціального конструювання, як соціальне формування техніки», тому «соціальна роль техніки гіпербалізується, тоді як інші важливі сегменти культури втрачають свої провідні позиції» [28, с. 354]. Перевагу національної самоідентифікації, зокрема українського архетипу кардіоцентризму як джерела національної ідеї в синтезі з іншою наскрізною структурою - ідеєю софійності як розуміння сутності явленого світу, обстоював С. Кримський, зауважуючи: «...особистістю є не тільки індивід, тобто якась фізична особа, особистістю є насамперед нація. Кожна нація $є$ неповторною. Нація - це історична особистість. Етнос перетворюється на націю тоді, коли стає суб'єктом історичного розвитку», і долає історичні перипетії зміцненням духовної культури, бо це - «створення свого власного внутрішнього світу, своєї особистості, тому що Бог розмовляє з людьми через їх особистість», i тому що «чим масштабніші духовні завдання ви собі ставите, тим більше у вас умов для щастя", для того, щоб нація залишалася непереможеною на шляху власної Одисеї, зокрема - освоєнні досвіду світової культури [29]. Лише так нація зможе увійти в культурну родину ЄС, де, за М. Барретом, культивують інтеркультуралізм, що «має на меті сформувати сильне почуття згуртованого суспільства, заснованого на загальнолюдських цінностях", позаяк «інтеркультурна компетенція не набувається автоматично: натомість їі потрібно вивчати, практикувати та підтримувати протягом життя. Формальні системи освіти відіграють важливу роль у цьому відношенні, і слід акцентувати увагу на інтеркультурній освіті протягом початкової, середньої та вищої освіти. Крім того, організації громадянського суспільства, релігійні громади та засоби масової інформації відіграють важливу роль, оскільки вони також можуть сприяти розвитку інтеркультурної компетенції людей», що включає «відкритість, емпатію, мульти-перспек- 
тивність, когнітивну гнучкість, комунікативну обізнаність, здатність адаптувати свою поведінку до нових культурних контекстів, а також лінгвістичні, соціолінгвістичні та дискурсивні навички, рахуючи навички управління спілкуванням» [1].

Мета: довести необхідність включення в процес інтеркультурного полілогу реактивації традиційних позицій самовизначення національної практики і теорії, переосмислених сучасною епістемологією та мистецтвознавчою аналітикою на засадах класичного естетичного досвіду, трансцендентних критеріїв оцінки і світовідчуття задля збереження духовного ядра національного культуротворення, всупереч гібридності мультикультурного контенту і волатильності арт-ринку.

Аналіз останніх досліджень і публікацій. Від 2000-х західний науковий дискурс стрясають різні теорії і принципи творчих практик, в тому числі ті, що свідчать про сплеск інтересу до техно-естетики Гілберта Сiмондона, виправдовуючи поширення дизайнпроектів паблік арт в контексті міста-генерика, що тонко висміює Рем Колхас. Багато публікацій (Моріс Берман, Сьюзан Джакобі) присвячуються смерті культури Заходу, колапсу американської мас-культурної свідомості. Але $є$ явно гібридні, як книга Патрика Б’юкенена, де досить дивно оголошується розпад Заходу наслідком домінування не транснаціонального капіталу, а анти-культури марксистів, що позбавили американське суспільство християнських цінностей [15]. Не менш гібридною є книга Кевіна МакКарті, де автор, досліджуючи негативні впливи волатильності ринку на культуру і мистецтво, вважає цю ситуацію незмінною, що суперечить оптимістичним інтеркультурним стратегіям «тhе White Paper» Єврокомісії [7; 1].

Окрема література розв’язувала питання системи вартісних орієнтирів посткультурного буття суспільства споживання, серед них і книга американського культуролога Джона Сібрука «Nobrow: The Culture of Marketing The Marketing of Culture» (2001), де він, зокрема, підкреслив розмивання дихотомії некомерційного та комерційного: «У аристократичної культури цінність визначалася якістю, а в культурі супермаркету - автентичністю. У аристократичної культури цінувалася послідовність культурних переваг, а в культурі супермаркету - переваги, що порушували традиційну культурну ієрархію. У аристократичної культури були присутні зміст і його реклама, а в культурі супермаркету кордону між ними не існувало» [12].

Мабуть, ця відсутність кордону пояснює факт швидкої адаптації маскультури в Україні як наслідування західноєвропейським патернам творчої діяльності, що відбувається за компліментарним сценарієм (бо комфортно плисти за mainstream), і зовсім ігнорується його критичний бік, що на теперішній час складає аналітичну противагу і в самому західному гуманітарному дискурсі. Тож заради справедливості слід вислухати і тих замовчуваних в сучасному українському просторі носіїв контраргументів, що попереджають про хиби векторів розвитку contemporary art, зокрема пластичних екзерсисів public art. I мова тут не стільки про відомі аналітичні системи, що пропонували Ф. Джеймісон чи П. Андерсон, про що вже не раз йшлося в моїх розвідках, скільки про міркування інших, менш відомих в нас аналітиків, згідно яким українцям слід замислитися про власні духовні цінності національної ідентифікації, що гуртують культурну еліту суспільства, надаючи змоги протистояти абсолютно непродуктивним, навіть руйнівним, геокультурним впливам ззовні.

Таких критичних аналітик небагато, але вони існують, протидіючи позиціям непасіонарних авторів, які змиряються з ризиками арт-ринку, що перетворює вільного митця на залежного прекаріата. Серед останніх вже згадуваний К. МакКарті, автор «A Portrait of the Visual Arts: Meeting the Challenges of a New Era» (2005) - третьої книги, присвяченій аналізу «драматичних змін» останніх 25 років в американських візуальних мистецтвах, викликаних суспільними змінами. Він наголошував на тому, що саме зміни в перевазі галузі розваг та відпочинку внаслідок посилення конкуренції в цій царині змінюють модель якісного вільного часу при нарощуванні фінансування державних і приватних інституцій культурної індустрії. Це вплинуло на трансформаційні процеси «екології мистецтв», зміну пріоритетних напрямів розвитку, творчі інтенції митців і те, як створюється і розповсюджується сучасний арт-продукт. Тож обставини конкурентного середовища приховують грізні виклики для мистецького розвитку, при тому, що науковці у повній «відсутності систематичного аналізу мистецтв» не мають сталої методології оцінки ситуацій в світовому артпросторі, не розуміються на знанні про роль циклічних факторів у фундаментальних суспільних зрушеннях, що "ускладнює визначення того, з якими сучасними проблемами стикається мистецтво»: «Без систематичного аналізу різних видів мистецтва - виконавських мистецтв, медіа-мистецтв, образотворчих мистецтв, літературних мистецтв важко визначити, наскільки зміни у споживчих ринках, організаційних структурах, фінансуванні, чи будь-які інші виклики, впливатимуть на різні художні дисципліни»; «У той же час, очевидно, ієрархія серед митців стає все більш розшарованою, як і перспективи їх заробітку. На вершині - кілька "суперзіркових" митців, чиї твори продаються за кордон за сотні тисяч, а іноді й мільйони доларів. У наступному ярусі - "бестселери", чиї роботи представляються та просуваються галереями, дилерами, аукціонними будинками та продаються за суттєвими цінами. На третьому щаблі - більшість митців-візуалів, які часто намагаються заробляти на життя продажом свого мистецтва. I ця зростаюча стра- 
тифікація значною мірою пояснюється змінами розміру та функціонування ринку мистецтв»; "Вплив ринкових сил на ринок мистецтв - це функція збільшення попиту, що виникає через зростаючу кількість високо-заможних людей та зміни ринкової практики» [7, с. XIII, XVI, XVII]. Автор переконаний, що «візуальна мистецька система історично відображала більш широку систему культури та суспільства, з яких вона походить", де теперішнє зростання числа колекціонерів пояснюється не стільки ростом поціновувачів, скільки інвесторів, тому він «розглядає образотворче мистецтво як систему, яка реагує на внутрішні та зовнішні сили", використовуючи «концептуальні рамки» аналізу задля кращого розуміння «зростання плюралізму в мистецьких стилях, нових технологій та змін суспільних очікувань щодо ролі візуального мистецтва в суспільстві» та впливу на усі ці елементи ринкового сектору. Позаяк кар'єрні патерни, як ринкова волатильність, $€$ нестабільними, мінливими, через що часто митці вимушені йти в дизайн, рекламу, інші комерційні арт-форми. Тому сам термін «мистецтво» також розмиває межі за рахунок нових медіа-арт чи перформативні візуальні проекти, і мистецтвознавчі методи аналізу щільно корелюють з техно-естетикою, концептуальними парадигмами, ринком.

Водночас у західної еліти виникають думки про небезпеку «спуску у варварство», де твори високих принципів алетеї суспільство консюмеризму буде сприймати лише різновидом «товару альтернативного штибу» (м. Берман) [2]. Невипадково у книзі «Rhetoric in Popular Culture» Барі Бруммет наголошує на складності визначення поняття "культура», що має численні субверсії, що міцно перетинаються; при цьому кожна з них впливає на свідомість, витлумачується ідеологією і функціонує як текст, що «визначається як набір знаків, пов'язаних один з одним, де сенс означає один і той же набір ефектів або функцій. Крім того, тексти - це способи, якими ми переживаємо культуру» [3, с. 27]. Бруммет диференціює «культуру як інтегрований набір або систему артефактів», де відбувається становлення спільноти, але їй протистоїть популярна культура, що «складається з тих систем артефактів, яким віддана більшість людей» [3, с. 39]. Питання в тому, що частина аналітиків вважає таку диференціацію нормою, але інші наполягають на тому, що "маскультура - нонсенс, позаяк культура завжди елітарна» (Д. Лихачов), і справжня інтелігенція, акумулюючи досвід націй, підіймає культуру суспільства до вершин знання, вершин культури, принаймні, нагадує К. МакКарті, навіть західно-європейські публічні музеї, що виникали наприкінці XIX сторіччя, мали «подвійну мету сприяння створенню мистецтва та піднесенню суспільного смаку", бо суспільство бачило the fine art явищем, «що має свою історію, і потребуючим особливого щабля чуттєвості» [7, с. 10].
Контекст епістемологічної гібридності суттєво впливає на формування мистецтвознавчих методів оцінки сучасної візуальної практики, потребуючи визначення усіх стратифікаційних нюансів. Адже комерційне мистецтво, отримуючи запаморочні інвестиції і гонорари (як от Вергард Вінге, якій за анальну творчість отримує від Культурної ради Норвегії \$4 M [5]), аж ніяк не є пріоритетним у культурному розвитку; між тим саме некомерційні форми мистецької практики, котрі у теперішній час суттєво відстають від комерційних (зокрема галерейних), будучи залежними від державної та волонтерської інвестиційної підтримки, визначатимуть культурно-мистецький щабель майбутнього, якщо суспільство завчасно не колапсує.

Виклад основного матеріалу. Гюстав Ле Бон ще в XIX сторіччі підкреслював: «стаючи часткою організованого натовпу, людина спускається на кілька сходинок нижче по сходах цивілізації» [22]. Розмірковуючи про важливість душі раси і нації для цивілізації, особливо коли до влади приходять пробивні люди 3 недорозвиненою культурою, Ле Бон стверджував: в критичні моменти потрясінь історії, коли свідомість людини трансформується, відбуваються тектонічні зміни цивілізаційних парадигм, приводячи до падіння імперій як «видимих результатів невидимих зрушень в людському мисленні». Така пролонгована трансформація в нових геополітичних і культурних умовах також непомітно змінює практичну і теоретико-методологічну свідомість, що рефлектує на наслідки гуманітарної біфуркації або тягнучи суспільство до гістерезису, або змушуючи його із над-зусиллям перейти на вищий щабель розвитку. За таких обставин поширюється епістемологічна гібридність, де хтось захищає технокультуру і неофрейдизм Жака Лакана, хтось - звинувачує в культурному падінні не ідеологію капіталу, а франкфуртців; хтось - відстоює духовні пріоритети самоідентифікації націй, але усі разом говорять про необхідність змін. У певному сенсі суперечка Платона і Аристотеля триває, і гештальт минулого опрацьовують як фізікалісти, так і прихильники негативної діалектики, нарікаючи один одному, як колись К. Юнг жорстко сперечався із 3. Фрейдом. (Попри те Європейська Рада, і «Біла книга» зокрема, враховує факт складності численних культурних ідентичностей, наголошуючи: всім людям «слід надати можливість розвивати свою багатомовну компетенцію, щоб вони були ефективнішими для участі в інтеркультурному обміні та діалозі з іншими", бо інтеркультуралізм уможливлює плюралізм та соціальну і культурну інтеграцію на засадах базових загальних цінностей, хоча і має недоліки, хиби стосовно питань культурних меншин, проте в цілому, на думку доктора Nasar Meer (Школа мистецтв і соціальних наук, Northumbria University, UK) i Tariq Modood, він тотожний старому терміну multiculturalism [1; 9, с. 175-196]). Зокрема Меер і Модуд зауважують, що від по- 
чатку, тобто на зламі 1960-70-х, «в Канаді та Австралії мультикультуралізм часто ототожнювався із застосуванням "ліберальних цінностей", оскільки мультикультуралізм у цих країнах розширював індивідуальні свободи та обгрунтовував обіцянку рівного громадянства», та наступна концепція інтеркультуралізму також пов'язана із політичним дискурсом, не маючи помітних успіхів у «роз'яснюванні різноманітних проблем, що випливають із складних ідентичностей» [9, с. 180, 192]. Втім є автори, які вперто винять у всіх гріхах саме ідею мультикультуралізму, політизація якої призвела до сепаратистських настроїв [13, с. 197-209].

Але існують в сучасному дискурсі і гібридні уявлення типових адептів посткультури, помітним серед яких є автор неологізму nobrow - символу глобалізаційних технологій редукції культури. Джон Сібрук, акумулюючи за трьома стратами комерційну культуру (індивідуальність, субкультура, культура мейнстріму) та елітну (висока культура, культура середнього інтелектуального рівня, масова культура), наголошує: «Якщо стара ієрархія була вертикальною, то нова ієрархія ноубрау існувала в трьох або більше вимірах. Субкультура виконувала ту ж роль, що колись і висока культура: тут вироблялися тенденції для культури взагалі. У ноубрау субкультура була новою високою культурою, а висока культура перетворилася лише в ще одну субкультуру. Але над субкультурою і мейнстримом перебувала ідентичність - єдиний загальний стандарт, кантіанська "суб'єктивна загальність"» [12]. Невідомо, чи перевернувся Кант при написанні цих слів Сібруком, але, мріючи подолати комерційний провал попередньої книги, і претендуючи на всеосяжне та водночас легке до сприйняття дослідження, цей автор створює справжній постмодерністський гібрид, що примирює з дійсністю консюмеризму, розваг, недолугим залученням загальновідомих фактів і тлумачень. Виправдовуючи падіння оціночної системи суспільства споживання до треш-щабля і підміну естетичної вартості твору медіа-рейтингом, він ставить високій культурі перворідним гріхом те, що саме їі елітарність, а не капіталістична система, «перетворила культуру в товар»: «Бастіон аристократичної культури сформувався в кінці вісімнадцятого століття, коли ставлення митця до тих, хто його фінансував, почало змінюватися. Меценатство згасало, читачі середнього класу і комерційні видавництва, навпаки, множилися, художники і письменники, які підпорядковувалися раніше диктату своїх покровителів, були кинуті на милість ринку. I якщо в деяких відносинах цей новий покровитель, ринок, виявився більш лояльним - художнику, наприклад, вперше була дана свобода у виборі тем для своєї творчості, - то в інших відносинах ринок виявився ще більшим тираном. Він був неосвічений, нечутливий, на нього легко було нагнати нудьгу, і він плювати хотів на високі стан- дарти старих покровителів» [12]. Тож комерційне мистецтво протистоїть некомерційному, що колись вважалось більш цінним, і у другій половині ХХ століття ринок перемагає: «У міру того як кордони між елітарною культурою і комерційної розмивалися, самі слова "комерційний" і "продатися" стали порожнім звуком. Питання старих культурних арбітрів на кшталт "Чи добре це?" i "Чи це Мистецтво?" були замінені питанням "Чиє це мистецтво?"» [20, с. 97-98]. Тобто «до дев’яностих років ідея, що висока культура є якоюсь вищою реальністю, а люди, які їі створюють, - вищими істотами, була відправлена на смітник», натомість у процесі розвитку мультимедійних діджитал-технологій «скорочувалась дистанція поміж митцем і його потенційною аудитоpiєю, і колись актуальна теза про захист митця від віроломного мейнстрим ринку втратив будь-який сенс»: «Технологія змінила саму природу авторства. Спрощення доступу автора до різноманітної інформації на потрібну йому тему зробило більш імовірною ситуацію, коли він міг користуватися чужими ідеями або принаймні змішувати свої ідеї з чужими. В Інтернеті, де будь-який текст можна наповнити гіпертекстовими посиланнями на інших авторів, відмова від фізичної роздільності текстів змінює традиційне розуміння авторства», тож поняття авторства розмивається, і «сучасний митець стає парадигмою процесу розкриття в собі творчих здібностей для всіх жителів планети». Схвалюючи культурну індустрію, автор завершує свої міркування вельми традиційно: «Голодуючий митець, мрійник, нездатний заробити на життя своїм мистецтвом, втратив своє значення як культурний архетип» [20, с. 292]. Сьогодні так і $€$, та ще на початку 2000-х існувала доволі критична до Сібрука позиція, де розвінчувався фестивалізм епохи арт-гламура, з притаманним «паразитуванням на авангардному імпульсі й з неприхованою тягою до рекламного глянцю»: «Фактично ідеологія гламуру $є$ ідеологією процвітаючого середнього класу, стурбованого комфортним життєвим дизайном і не бажаючого кардинальних соціальних змін. Тому ця ідеологія, насаджуючи норми безтурботного fun'a, грайливого cool'a i затишної релаксації, відрізняється шаленою войовничістю. <...> Риторика гламуру, будучи сублімацією такої агресивної пасивності, звеличує відмову від соціальних подолань, естетичних проривів і етичного запитування. Відтак гламурне сучасне мистецтво орієнтоване на відстоювання інституційної та ринкової стабільності, на створення інертних і продажних (у всіх сенсах) соціокультурних моделей» [18]. Безумовно, протистояння ненаситним амбіціям консюмеризму і анархії несмаку з боку прихильників чи-то стратегій високої класики, чи-то стратегії «пасивної агресивності» проти агресивної пасивності ринковокомодифікованого артизму на теперішній час виглядає програшним, хоча ще десятиріччя тому мало потужність (бо «чим жорстокішім 
на початку 2000-х робиться натиск гламуру у масштабах найбільших бієнале або ярмарків, - тим активніше в мистецьких колах усвідомлюється необхідність радикальної відсічі такої масованої атаки» [18]), але той, хто розуміється на циклових еволюційних законах, знає: історія повторюється, і кінець доби ноубрау так само неминучий.

Однак що нам, сьогоднішнім українцям, в цій гібридній боротьбі, якщо вже аналітики визнали: сьогодні все гібридне - і війни, і мистецтво, і наукові теорії? Тим більше, що С. Хантингтон ще у 1990-х попереджав про ризики України, що стоїть на тектонічних геополітичних, геокультурних, сакральних розломах, про ризики для Криму і Донбасу, і мав рацію в прогнозах; та водночас він застерігав не втрачати пильності стосовно експансії західної soft-power, що уніфікує світову культуру, хоча нав'язування сильними державами своєї культури слабким не покращує, а принижує культури економічно нерозвинених країн. Тому періодично виникає рух індихенізму, що рятує нації від зникнення. Ф. Джеймісон також дотримується цієї думки, підкреслюючи: коли центр сучасної західної культури (США) охопив вир культурної ентропії, периферійним зонам цієї посткультурної імперії випадає щасливий шанс відродження власних культур і мистецтв на ендемічному грунті традицій. Виходить, через цю гибридність наукового дискурсу українцям, особливо молодим фахівцям, митцям і вченим, слід зважувати кожну методологічну позицію, кожну тезу теорій, недарма ж сказано "чужому навчайтесь, й свого не цурайтесь». Але гібридна вітчизняна художня практика нехтує національною ідентичністю, натомість демонструє запаморочливий успіх, зокрема в міжнародному контексті public art, де українці, завзято тиражуючи техно-естетику і заробляючи як найманий прекаріат, не зацікавлені в критичному мисленні, тим знищуючи національне самоідентифікаційне творче ядро, і тут не варто відмахуватися від проблеми банальною констатацією того, що «візуальні митці в широкому розумінні можуть включати не тільки малярів та скульпторів, але й дизайнерів, графіків та архітекторів», що і так зрозуміло [7, с. 44]. Проблема в тому, що згідно даних, що наводить К. МакКарті, станом на 2000 рік відсоток фахових митців США (скульптура, малярство, графіка, ужиткове мистецтво), складає від усіх творчих професій лише 12 \% (це 250 тис., трохи більше ніж архітекторів, і відсоток продовжує зменшуватися). Найчисельнішими є дизайнери (65 \%), причому тут не врахований відсоток тих скульпторів чи графіків, хто перестає працювати за фахом і свідомо починає працювати як дизайнер, до того ж «ринок візуальних мистецтв не має прямого аналога в інших видах мистецтва", але маркетингові зміни торкнулися розуміння соціумом як «природи мистецтва, що твориться, так і форм дискурсу про мистецтво», причому тут за необхідності при- пускається навіть маніпуляція зі статусом артоб’єктів, як, «наприклад, обидва головні аукціонні будинки Christie's та Sotheby's неодноразово змінювали темпоральні межи визначення modern та contemporary art» [7, с. 45, 61, 62]. Обидва будинки, змінюючи профіль з оптової закупівлі на роздрібну торгівлю, стали домінуючими гравцями, поступово формуючи арт-ринок, зокрема contemporary art, протягом 1980-х, що стало наслідком двадцятирічної діяльності Пітера Вілсона (Peter Wilson) на посту голови Сотбісу, контроль над яким купив у 1983 році Альфред Таубман (Alfred Taubman), започаткувавши додаткові маркетингові кроки (глянцеві каталоги, передпокази, висвітлення 3МІ подій як вагомого явища мистецького буття): «Величезне зростання ринку мистецтв, яке розпочалось у 1980-х, спричинило кілька кардинальних змін у його діяльності. Мабуть, найголовніше було в тому, як оцінювались твори мистецтва та встановлювали ціни», і ключовим питанням «було те, які твори та митці заслуговують на визнання ïx "легітимними"», відтоді "велика частина модерністського дискурсу про візуальне мистецтво у XX столітті обернулася питанням того, що вважати мистецтвом і як відрізнити мистецький твір від звичайної речі», при цьому вартісний критерій «легітимності» залежав від рішення експертів, дилерів, відомих колекціонерів і кураторів, де частіше виникає спекуляція [7, с. 64, 67]. Тож «чим вища ціна, тим більший попит», адже "глобалізація ресурсів сприяє глобалізації попиту та вступу інших посередників», що посилює глобалізацію арт-ринку, заохочуючи потенційних інвесторів спекулювати на contemporary проектах, "довгострокова цінність яких ще не встановлена»: «Зміни на елітному ринку за останні 30 років не тільки призвели до різкого зростання цін, але й змінили роль та значення різних гравців на ринку", більшість з яких отримала величезні фінансові прибутки [7, с. 66, 70, 72]. Серед лузерів, зазначає К. МакКарті, опинилися неконкурентоздатні музейники та мистецтвознавці, критики, думка яких щодо легітимності того чи іншого твору більше не була потрібною. I це було очікуваним. «Модернізм почав набирати переваги в американському мистецтві після Першої світової війни. Його послідовні формулювання, що розумілися на рівні авангардного прогресу в уявленні про природу мистецтва, формувались у різних стилях і рухах. Учасники світового мистецтва розуміли, що ці стилі та рухи торують більшу траєкторію історії мистецтва» [7, с. 12-13], проте від 1970-х постмодерний плюральний дискурс теорії і практики став ще більш багатовимірним, де частина естетичних оцінок перебудувалася і почала керуватися комерційною прерогативою, і хоча жоден рух чи стиль не претендував на верховенство, але video art, installations, digital art вийшли на превалюючі позиції візуальних практик, просуваючись завдяки старанням власної мережі критиків, видань, колекціонерів, галерей. «Плюраліза- 
ція мистецького дискурсу проклала шлях до появи безпрецедентного мистецького різноманіття, а разом із цим надзвичайно швидкого розширення та сегментації мистецького ринку», процес пришвидшувався, адже від зламу XVIII-XIX століть «система гільдій та академій поступилася місцем ринковій системі розподілу мистецтв», і на зламі XIX-XX століть американський арт-ринок почав процвітати, бо «кілька найбагатших промислових титанів нації зацікавились мистецтвом і були готові та змогли витрачати свої багатства» [7, с. 13-14]. Тож протягом 1980-х аукціонні ціни з шестизначними показниками стали звичним явищем, проте, навіть з урахуванням того, що такі найбагатші колекціонери, як Чарльз Саатчі, «який може формувати цілі сегменти ринку мистецтв, жоден колекціонер сьогодні не наближається до витрат королівських меценатів та магнатів раннього капіталізму» [7, с. 15]. Та не можна заперечувати: «ескалація ринкових цін призвела до появи персонажів, що підпадають під сучасну культурну індустрію», передусім нового сервісу обслуговування економічних потреб візуальних практик: від страхування і спеціальних банківських послуг, чи інвестиційних консорціумів, до кураторів, консультантів і менеджерів зі зв'язків з громадськістю, так що сьогодні констатують народження the Age of the Art Industry, бо "The Art World Is Over". К. МкКарті апелює до відомостей, згідно яких в Америці останніх 25 років «колекціонування сучасного мистецтва є вдвічі популярнішим, ніж колекціонування модерну...; втричі популярнішим, ніж колекціонування імпресіоністів, і в чотири рази популярнішим, ніж колекціонування старих майстрів» [7, с. 30].

Зрозуміло, ця ситуація впливає на свідомість митців, на їхні творчі принципи, на бажання скорішого отримання визнання, ніж то відбулось би природнім шляхом поступового внутрішнього дозрівання, тому деякі аналітики, як от Роберт Хьюз (Robert Hughes) чи Пітер Плагенс (Peter Plagens), констатують негативні наслідки від скорочення традиційних темпів розвитку митців, проекти яких фактично вбудовані в контекст стратегій культуріндустрії розваг. Та більшість аналітиків, подібно до К. МакКарті, вважають, що не зважаючи на «швидке зростання мистецького світу, яке почалося в 1960-х» і тепер сповільнюється змінюючись, старі стандарти якості не повернуться, бо мистецький простір тепер поділений на комерційний та некомерційний сектори, візуальні практики зручні для легкого і швидкого сприйняття, підходячи до американського способу буття, і «зміни на елітному ринку не будуть відмінені, а традиційна система присвоєння вартості та ціни не буде відновлена», проте не викликає сумніву той факт, що «участь у світовому дискурсі візуальних мистецтв потребує спеціалізованих знань, при тому що їх часто не розуміють навіть фахівці зі значною підготовкою» [7, с. 105]. Отже, на тлі «занепаду модерністського ка- нону світовий мистецький дискурс стає все більш плюралістичним і менш концентрованим на вузькому колі експертів», митці спрямовують власну кар'єру на ринок, як і художні музеї , які «все частіше переводять свою головну увагу зі своїх колекцій на залучення громадськості», втім у цих умовах залишається актуальним питання «як організаційна екологія мистецтв може адаптуватися до мінливого соціального середовища, не відмовляючись від центрального ядра досвіду візуальних мистецтв?» [7, с. 106, 109]. Одна з відповідей стосується участі в долі мистецького розвитку державного фінансування чи спеціальних культурних фондів, що впливатимуть на формування майбутнього попиту на певні форми мистецтва, через що виникає побоювання, що подібне «фінансування художників незмінно може бути пов'язане зі спробами уряду контролювати зміст мистецтва", що штучно викривлятиме ринок, який все ж не повернеться до стану перед 1960-ми [7, c. 113-114].

Відсоток загальновідомих митців ще суттєвіше зменшується через те, що існує два артринка: еліт-ринок для тих зіркових митців, які у фокусі уваги культуріндустріальних топових критиків, кураторів, комерційних галерей, аукціонів, престижних дилерів і меценатів; та загальний арт-ринок для усіх інших митців. «Таким чином, художники, які діють на елітному ринку, швидше за все, відрізнятимуться від тих, хто продає свої роботи на загальному ринку, і зокрема - престижем серед спільноти visual art», щоправда автор справедливо додає: "не існує чіткого способу визначити, до якого класу належать професійні митці-візуалісти», і фактор випадковості вибору тут має значення більше, ніж істинна фахова якість. Тому на зламі міленіумів «надзвичайний ріст ринку мистецтв викликав питання щодо його довгострокового впливу на якість мистецтва в цілому - особливо серед тих, хто побоюється, що подальше зростання буде спричинене спекуляціями», адже «галереї та дилери часто субсидують митців до тих пір, поки попит на їх роботу (зазвичай 5-7 років) не забезпечив достатній дохід для покриття цих витрат. Справді, у таких галереях, як Лео Кастеллі, був принаймні один співробітник, який розвідував нових перспективних митців» [7, с. 42, 46, 55]. Тож митці (інновації яких були спрямовані на арт-ринковий успіх) прагнули підтримати довгострокові стосунки 3 дилерами, сподіваючись на зростання попиту на їхні твори, а дилери конкурували між собою за митців 3 класу «зіркових" чи «бестселерів» задля комерційного успіху, підігріваючи ринкові ціни, використовуючи рекламу, аукціонні передпродажні покази і глянцеві каталоги, заохочуючи колекціонерів. Це спонукає менш комерційно успішних митців до маркетингових кроків, щоб звернути до себе увагу 3MI, критиків і кураторів "мікрогалерей», що не є дилерами, але зусиллями яких заповнюється ринковий простір ниж- 
чого сегменту, даруючи надію на просування в культуріндустріальній ієрархії. Зрозуміло, що про естетичну вартість творчих принципів в умовах пошуку «балансу між попитом та пропозицією» тут не йдеться, але стає визначальною суб'єктивна думка дилера, і соціум приймає таку стратегію комерційного існування артизму. Відповідно К. МакКарті наголошує: від 1970-х, коли в Америці зростала популярність університетської підготовки митців нової генерації, в культурному просторі закріплюється розуміння мистецтва як сфери інвестицій, де категорія фахової майстерності втрачає вагу перед привабливістю застосування нових технологій та використання арт-простору як приводу для концептуальних розмов. Прагматизм експериментувань призвів до того, що «візуальні митці почали працювати із значно більш різноманітним діапазоном медіа», а «надзвичайне зростання ринку візуальних мистецтв, зокрема просування концепції мистецтва як інвестиційного засобу, спонукав як колекціонерів, так і спекулянтів розглядати сучасне мистецтво подібним до ф’ючерсного ринку", що відгукнулося несталістю цінової політики арт-ринку, еклектикою стильових інтенцій та рішеннями митців «або змінити фах, або отримати більш стабільну зайнятість у кар’єрі», як наслідок: на зламі міленіумів, "незважаючи на різке зростання цін на ринку мистецтв, зростання кількості нових малярів та скульпторів у цей період різко впало» [7, с. 56-58, 59]. Не дивно тому, що і в Україні, де поки що подібні проблеми не вивчаються, процеси відтоку фахових малярів й скульпторів 3 ендемічних галузей у суміжні, зокрема у ландшафтний дизайн, як от паблік арт, набуває обертів. І у відсотковому співвідношенні тих, хто залишився вірним набутому фаху, на теперішній час маємо суттєво мале число. Але за звичкою колишні скульптори свою дизайнпродукцію продовжують видавати за скульптуру, і вітчизняні критики, не відчуваючи маніпулятивної підміни, розглядають подібні об’єкти як справжню скульптуру. Така ситуація чревата тим, що втрачається рівень майстерності, і коли митці повертаються у лоно фігуративної пластики, то стикаються зі шкільними помилками, зокрема не вміючи провести вірну систему відбору форм задля втілення образу, не впадаючи при цьому у брутальний натуралізм, де за анімальною тілесністю немає нічого, що належить царині високого мистецтва. Все це $є$ наслідком тих руйнівних процесів, які аналізували вітчизняні фахівці, констатуючи: «Нанотехнології, біотехнології, інформатизація не тільки детермінують подальший розвиток культури, а й змінюють світогляд сучасної людини, де справжнє, природне, об'єктивне заміщується штучним, віртуальним, симульованим. Як наслідок, індивід є дезорієнтованим у своїх ціннісних орієнтаціях, ідентичності, його світогляд постає фрагментарним, а поведінка - непередбачуваною. Відтак, людина поступово пе- ретворюється із суб’єкта дії на об’єкт техносфери, не усвідомлюючи того, що результати iï праці (Інтернет, соціальні мережі, засоби сучасного зв'язку) не мають замінювати собою світ (природний, соціальний), а повинні використовуватися як засоби підвищення продуктивності діяльності» [17, с. 166]. Тож в сучасних умовах гібридної культури, що міксує масову і елітну складову, якість "духовості» зникає, технокультура їі ігнорує. Але без гуманістичного трансцендентного наповнення така культура руйнує людину, що «відмовляється й від антропологізму», тобто «людина перетворюється на фактор технологічного прогресу, який повністю поглинає їі», тому і мистецький твір «вже не стільки є пошуком соціальної значимості, цінності, а скоріше розглядається як комерційна успішність, тобто сприймається як товар», і митці тиражують свої твори, бо «постмодернізм пропонує говорити про постлюдину в рамках постантропології. Основними категоріями якої $є$ хаос, вакуум, віртуальність, штучність, а базовим принципом $€$ повторення" [17, с. 169]. Проте для виживання культури і мистецтва в умовах посткультури ми маємо «не тільки пережити ще одну кризу (культурно-антропологічну), а й знайти шляхи подальшого власного розвитку» [17, с. 170].

Факт нерозуміння того, що технокультурна формалізація буття небезпечно підмінює самоідентифікацію людини, по-своєму висловила і Марта Фаріон, президент КиєвоМогилянської фундації в США, згадуючи про те, що перша і друга хвилі мігрантів змогли вижити і асимілюватися завдяки міцній історичній пам'яті, що підтримує віру, культуру, мову, спосіб життя в осередках діаспори; та хвиля 1980-х років вже прагне розчинитися в американській культурі, втрачаючи ідентичність, стаючи безликою, тому в міленіум страждає від тих ментальних хвороб, що i американці [25]. Відтак слова Б’юкенена, спрямовані до американців, які з 2000-х віддають пріоритет контркультурі університетських кампусів, втрачаючи в потоках мігрантів свою ідентичність, дієві і для митців України, бо щоб знищити націю, досить позбавити народ пам'яті історії та культури i «нація втратить свою місію, цей дар небес»; але «яка сила може протистояти пісні сирен гедоністичної культури», що «формує громадську думку через телебачення, кінематограф, театр, журнали і музику» [15]. Цю силу Б’юкенен бачить у християнської вірі, але при цьому вважає критику капіталізму фейком, - проте надзвичайно нелогічним здається з позицій цього автора виправдання ним смерті в Хіросіми і Нагасакі, В’єтнамі та під час путчу в Чилі. Віра Б’юкенена виявляється химерою через політичний підтекст (за іронією, саме таку позицію щодо тріумфу віри і капіталізму обстоював Аятола Рухолла Хомейні, який ненавидів США і СРСР). Не випадково багато аналітиків порівнюють могутність США з останніми роками Римської 
імперії, цитуючи Ле Бона, зокрема в аспекті психології натовпу.

Чи бажає Україна наслідувати «символічний мультикультуралізм», чи прагне відстоювати власного виробництва справжне мистецтво майбутнього, що збагатить світове? Від відповіді на це питання залежить доля національного культуротворення.

Висновки. Таким чином, зафіксовану С. Хантингтоном слабкість України ми маємо перетворювати на потужну силу, тобто довести спроможність явити у світовому куль- турному просторі не об’єкта, але суб'єкта активних культуротворчих дій, не копіювати агонію вмираючих імперій, але створювати вітальну з міцною аурою духовості культуру, на основі зняття конфліктних суперечок між традиціями середземноморського "гелінізму» (Д. Чижевський) й неогегельянскою романтично-пісенною чуттєвістю у синергії емпатіїекстазису. Тільки так ми уникнемо «болота мас-культури» (П. Б’юкенен), де тоне Захід, тягнучи за собою усю цивілізаційну культуру.

\section{Література}

1. Barrett M. Interculturalism and Multiculturalism: Similarities and Differences. Strasbourg: Council of Europe Publishing, 2013.

2. Berman M. The Twilight of American Cultural. W. W. Norton \& Company; Reprint edition, 2001. 224 p. 3. Brummett B. Rhetoric in Popular Culture / University of Texas at Austin. 2nd ed. Thousand Oaks, London, New Delhi: Sage Publications, 2006.

4. Buchanan P. The Death of the West // Official Website. URL https://buchanan.org/blog/death-westleather-bound-signed-pat-buchanan

5. Cane Lionel Du. Norway: "Artist” who spray-paints with anus receives $\$ 4 \mathrm{M}$ in Public Funds // National File. December 11, 2019. URL https://nationalfile.com/norway-artist-who-spray-paints-with-anus-receives4m-in-public-funds/

6. Grillo R. (University of Sussex). But What is Interculturalism? / DRAFT, December 2016. URL https://www.academia.edu/30455789/But_What_IS_Interculturalism?email_work_card=thumbnail

7. McCarthy Kevin F. A Portrait of the Visual Arts: Meeting the Challenges of a New Era / RAND Corporation, 2005.

8. McCarthy Kevin F. The Performing Arts in a New Era / RAND Corporation, 2001.

9. Meer N., Modood T. How does Interculturalism Contrast with Multiculturalism? // Journal of Intercultural Studies. University of Bristol. Vol. 33, № 2, April 2012.

10. Modood T. Interculturalism: Not a new policy paradigm // Comparative Migration Studies. 2018. URL https://www.academia.edu/36867780/Interculturalism_Not_a_new_policy_paradigm?auto=abstract

11. Modood T. Must Interculturalists Misrepresent Multiculturalis? // Comparative Migration Studies. Multiculturalism-Interculturalism. 8 September 2017. URL https://comparativemigrationstudies.springeropen.com/multiculturalism-interculturalism

12. Seabrook J. NoBrow: The Culture of Marketing - The Marketing of Culture / Publisher: Knopf, 2000. $224 \mathrm{p}$.

13. Werbner P. Multiculturalism from Above and Below: Analysing a Political Discourse // Journal of Intercultural Studies. University of Bristol. Vol. 33, № 2, April 2012.

14. Бадьйор Д. Олена Червоник: «В Україні дуже крута візуальна культура, але досі збіднілий та неадекватний опис цієї культури» // LB.ua, 10.12.2019 URL https://lb.ua/culture/2019/12/10/444416_olena_chervonik_v_ukraini_duzhe_kruta.html

15. Бьюкенен П. Дж. Смерть Запада. Москва: АСТ, 2003. 448 с.

16. Вийти з нинішніх випробувань сильнішими. Звернення Групи «Першого грудня» // Ініціативна група «Першого грудня». 04.11.2019. URL http://1-12.org.ua/?p=4183\&preview=true

17. Власенко Ф., Левченюк Є., Товмаш Д. Посткультура в контексті трансгуманізму // Вісник НАКККіM. 2019. № 2. С. 166-170.

18. Голынко-Вольфсон Д. Агрессивно-пассивный гламур // Художественный журнал, № 60, декабрь 2005. URL http://xz.gif.ru/numbers/60/glamur/

19. Дорошенко К. Десять українських митців десятиріччя. Рейтинг Костянтина Дорошенка // Суспільне | UA. 28.12.2019. URL https://suspilne.media/6824-desat-ukrainskih-mitciv-desatiricca-subektivnijrejting-kostantina-dorosenka/

20. Ініціативна група «Першого грудня». Декларація. URL http://1-12.org.ua/deklaratsiya

21. Лавріненко О. Євген Сверстюк: «Утрачено той рівень культури, який зобов’язує до сповідування вершин і плекання принципу правдивості» // День. Інтелектуальні Дискусії. № 207. 6.11.1999. URL https://day.kyiv.ua/uk/article/osobistist/ievgen-sverstyuk-utracheno-toy-riven-kulturiyakiy-zobovyazuie-do-spoviduvannya

22. Ле Бон Г. Психология народов и масс / Книга ІІ. Психология масс. СПб: Макет, 1995.

23. «Не все одно, в якій країні ми живемо. Бо "все одно" - значить "мені байдуже"» - Предстоятель УГКЦ Святослав // Про Львів. 04.01.2020. URL https://prolviv.com/blog/2020/01/04/

24. Офіційна веб-сторінка Мартіна Баррета: www.martynbarrett.com

25. Руда О. Українська діаспора Чикаго. Інтерв’ю з Мартою Фаріон. 9.09.2019 // Ukrainian People. URL http:// https://ukrainianpeople.us/\%

26. Сибрук Д. Nobrow. Культура маркетинга. Маркетинг культуры. Москва: Ad Marginem, 2004. 
27. Славінська I. Мирослав Попович: Українська наука — це гетто // Українська правда. 25 травня 2011. URL https://ife.pravda.com.ua/culture/2011/05/25/79321/

28. Трач Ю. В. Проблеми вивчення культури в світлі ї̈ взаємодії з технікою // Вісник НАКККіМ. 2019. № 3. C. 352-356.

29. Ціон В. За межею щастя і нещастя (монолог С. Кримського) // ZN.UA 24 червня 2011. URL https://dt.ua/SOCIETY/za_mezheyu_schastya_i_neschastya.html

\section{References}

1. Barrett M. Interculturalism and Multiculturalism: Similarities and Differences. Strasbourg: Council of Europe Publishing, 2013.

2. Berman M. The Twilight of American Cultural. W. W. Norton \& Company; Re-print edition, 2001. 224 r. 3. Brummett B. Rhetoric in Popular Culture / University of Texas at Austin. 2nd ed. Thousand Oaks, London, New Delhi: Sage Publications, 2006.

4. Buchanan P. The Death of the West // Official Website. URL https://buchanan.org/blog/death-westleather-bound-signed-pat-buchanan

5. Cane Lionel Du. Norway: “Artist” who spray-paints with anus receives \$4 M in Public Funds // National File. December 11, 2019. URL https://nationalfile.com/norway-artist-who-spray-paints-with-anus-receives4m-in-public-funds/

6. Grillo R. (University of Sussex). But What is Interculturalism? / DRAFT, Decem-ber 2016. URL https://www.academia.edu/30455789/But_What_IS_Interculturalism?email_work_card=thumbnail

7. McCarthy Kevin F. A Portrait of the Visual Arts: Meeting the Challenges of a New Era / RAND Corporation, 2005.

8. McCarthy Kevin F. The Performing Arts in a New Era / RAND Corporation, 2001.

9. Meer N., Modood T. How does Interculturalism Contrast with Multiculturalism? // Journal of Intercultural Studies. University of Bristol. Vol. 33, \# 2, April 2012.

10. Modood T. Interculturalism: Not a new policy paradigm // Comparative Migration Studies. 2018. URL https://www.academia.edu/36867780/Interculturalism_Not_a_new_policy_paradigm?auto=abstract

11. Modood T. Must Interculturalists Misrepresent Multiculturalis? // Comparative Migration Studies. Multiculturalism-Interculturalism. 8 September 2017. URL https://comparativemigrationstudies.springeropen.com/multiculturalism-interculturalism

12. Seabrook J. NoBrow: The Culture of Marketing — The Marketing of Culture / Publisher: Knopf, 2000. $224 \mathrm{p}$.

13. Werbner P. Multiculturalism from Above and Below: Analysing a Political Dis-course // Journal of Intercultural Studies. University of Bristol. Vol. 33, \# 2, April 2012.

14. Bad `jor D. Olena Chervony`k: «V Ukrayini duzhe kruta vizual `na kul `ura, ale dosi zbidnily`j ta neadekvatny`j opy`s ciyeyi kul`tury`» // LB.ua, 10.12.2019 URL https://lb.ua/culture/2019/12/10/444416_olena_chervonik_v_ukraini_duzhe_kruta.html

15. B yukenen P. Dzh. Smert`Zapada. Moskva: AST, 2003. $448 \mathrm{s.}$

16. Vy`jty`z ny`nishnix vy`probuvan`sy`l`nishy`my`. Zvernennya Grupy` "Pershogo gru-dnya» // Iniciaty "vna grupa «Pershogo grudnya». 04.11.2019. URL http://1-12.org.ua/?p=4183\&preview=true

17. Vlasenko F., Levchenyuk Ye., Tovmash D. Postkul `tura v konteksti transgumani-zmu // Visny`k NAKKKiM. 2019. \# 2. S. 166-170.

18. Golыnko-Vol `fson D. Agressy `vno-passy `vnыj glamur // Xudozhestvennыj zhurnal, \# 60, dekabr` 2005. URL http://xz.gif.ru/numbers/60/glamur/

19. Doroshenko K. Desyat ‘krayins `ky ‘x my `tciv desyaty`richchya. Rejty `ng Kostyanty `na Doroshenka // Suspil `ne |UA. 28.12.2019. URL https://suspilne.media/6824-desat-ukrainskih-mitciv-desatiricca-subektivnij-rejting-kostantina-dorosenka/

20. Iniciaty "vna grupa «Pershogo grudnya». Deklaraciya. URL http://1-12.org.ua/deklaratsiya

21. Lavrinenko O. Yevgen Sverstyuk: «Utracheno toj riven ` kul `tury`, yaky `j zo-bov'yazuye do spoviduvannya vershy`n i plekannya pry`ncy`pu pravdy`vosti»// Den `. Inte-lektual `ni Dy`skusiyi. \# 207. 6.11.1999. URL https://day.kyiv.ua/uk/article/osobistist/ievgen-sverstyuk-utracheno-toy-riven-kulturiyakiy-zobovyazuie-do-spoviduvannya

22. Le Bon G. Psy`xology`ya narodov y` mass / Kny`ga II. Psy`xology`ya mass. SPb: Ma-ket, 1995.

23. «Ne vse odno, v yakij krayini my`zhy vemo. Bo "vse odno" — znachy`t` "meni baj-duzhe"» — Predstoyatel `UGKCz Svyatoslav // Pro L `viv. 04.01.2020. URL https://prolviv.com/blog/2020/01/04/

24. Oficijna veb-storinka Martina Barreta: www.martynbarrett.com

25. Ruda O. Ukrayins `ka diaspora Chy `kago. Interv'yu z Martoyu Farion. 9.09.2019 // Ukrainian People. URL http:// https://ukrainianpeople.us/\%

26. Sy`bruk D. Nobrow. Kul `tura markety`nga. Markety`ng kul`turы. Moskva: Ad Marginem, 2004.

27. Slavins `ka I. My`roslav Popovy`ch: Ukrayins `ka nauka — ce getto // Ukrayins `ka pravda. 25 travnya 2011. URL https://life.pravda.com.ua/culture/2011/05/25/79321/

28. Trach Yu. V. Problemy`vy`vchennya kul `tury`v svitli yiyi vzayemodiyi z texnikoyu // Vi-sny `k NAKKKiM. 2019. \# 3. S. 352-356.

29. Cion V. Za mezheyu shhastya i neshhastya (monolog S. Kry`ms `kogo) // ZN.UA 24 cher-vnya 2011. URL https://dt.ua/SOCIETY/za_mezheyu_schastya_i_neschastya.html 
Protas M.

Art Studies in the Context of Epistemological Hybridity

In the context of contemporary European discussion on the mutual integration or divergence of intercultural and multicultural paradigms, in the conditions of epistemological hybridity and dominance of art-market volatility, driving factors behind a number of peculiarities of the development of national cultural and artistic being are specified, and downsides of a judgemental criteria in the field of art studies are accentuated. The importance of reactivating the traditional aspects known as the "spirituality" of theory and practice, or as the Kantian-Hegelian criteria of aesthetic experience, is stressed.

Keywords: self-identification, national art, memory culture, commodified art, epistemological hybridity, analysis criteria, interculturalism, multiculturalism.

Протас М. А.

Искусствоведение в контексте эпистемологической гибридности

В контексте современной европейской дискуссии о взаимной интегрированности или несоответствии интеркультурной и мультикультурной парадигм, в условиях эпистемологической гибридности и доминирования волатильности арт-рынка выясняются причины ряда особенностей развития национального культурно-художественного бытия, акцентируются ошибки искусствоведческих оценочных критериев, а также делается акцент на важности реактивации традиционных аспектов, известных как «духовость» теории и практики, или как кантовско-гегелевский принцип восприятия эстетического опыта.

Ключевые слова: самоидентификация национального искусства, культура памяти, комодифицированное искусство, эпистемологическая гибридность, критерии анализа, интеркультурализм, мультикультурализм. 